\title{
FORMATION OF DYNAMICALLY STABLE LAKESHORE UNDER SEASONALLY CHANGING WAVE DIRECTION
}

\author{
Toshinori Ishikawa ${ }^{1}$, Takaaki Uda ${ }^{1}$, Toshiro San-nami ${ }^{2}$ and Shusuke Watanabe ${ }^{2}$
}

\begin{abstract}
In the Ukishima region of Lake Kasumigaura, beach nourishment along with the construction of groins has been carried out to recover a sandy beach. After the beach nourishment, part of the nourishment sand was transported away from the beach, turning around the tip of the downcoast groin owing to the oblique wave incidence in winter. To enhance the stability of the beach, the groins were extended and a spur dike was constructed. To design these structures, a numerical simulation using the BG model was carried out, and the optimum shapes were determined by taking into account the seasonally changing wave direction. The effectiveness of the spur dike was numerically evaluated using the BG model.
\end{abstract}

Keywords: lakeshore changes; Lake Kasumigaura; BG model; seasonal changes; spur dike; beach nourishment

\section{INTRODUCTION}

Lake Kasumigaura, which has an area of $171 \mathrm{~km}^{2}$ and a mean water depth of $4 \mathrm{~m}$, is the second largest lake in Japan and is located in the Kanto plain, as shown in Fig. 1. In this lake, wind waves with a significantly large wave height sometimes occur because of the long fetch in some directions. The sandy beaches of this lake were used for swimming in the past, but recently they have been lost owing to various anthropogenic factors such as the construction of seawall and fishing ports, and sand mining from the lakebed (Fig. 2). To recover the sandy beaches, plans to carry out beach nourishment were initiated in 2006, and beach nourishment using $6,350 \mathrm{~m}^{3}$ of sand dredged from the lakebed was experimentally carried out along with the construction of four groins in 2007 in the Ukishima region of this lake, as shown in Fig. 3. The lengths and intervals between the groins were designed taking into account the predominant wave direction and the minimum beach width of $20 \mathrm{~m}$ necessary for preventing wave run-up to the dike. According to the results of a monitoring survey after beach nourishment, some sand was transported away from the beach and turned around the tip of one of the groins constructed to block longshore sand transport. Theoretically, wind at a lake can blow from any direction, resulting in a much larger wave incidence angle to the shoreline than that of exposed beaches facing the open ocean. The discharge of part of the nourished sand is attributed to this large wave incidence angle. In this study, the effect of this oblique wave incidence with a large angle on the beach changes was investigated through the analysis of monitoring survey data and a numerical study using the BG model, which was proposed by Serizawa et al. (2006), and the effectiveness of a spur dike as a measure to stabilize the beach was studied.
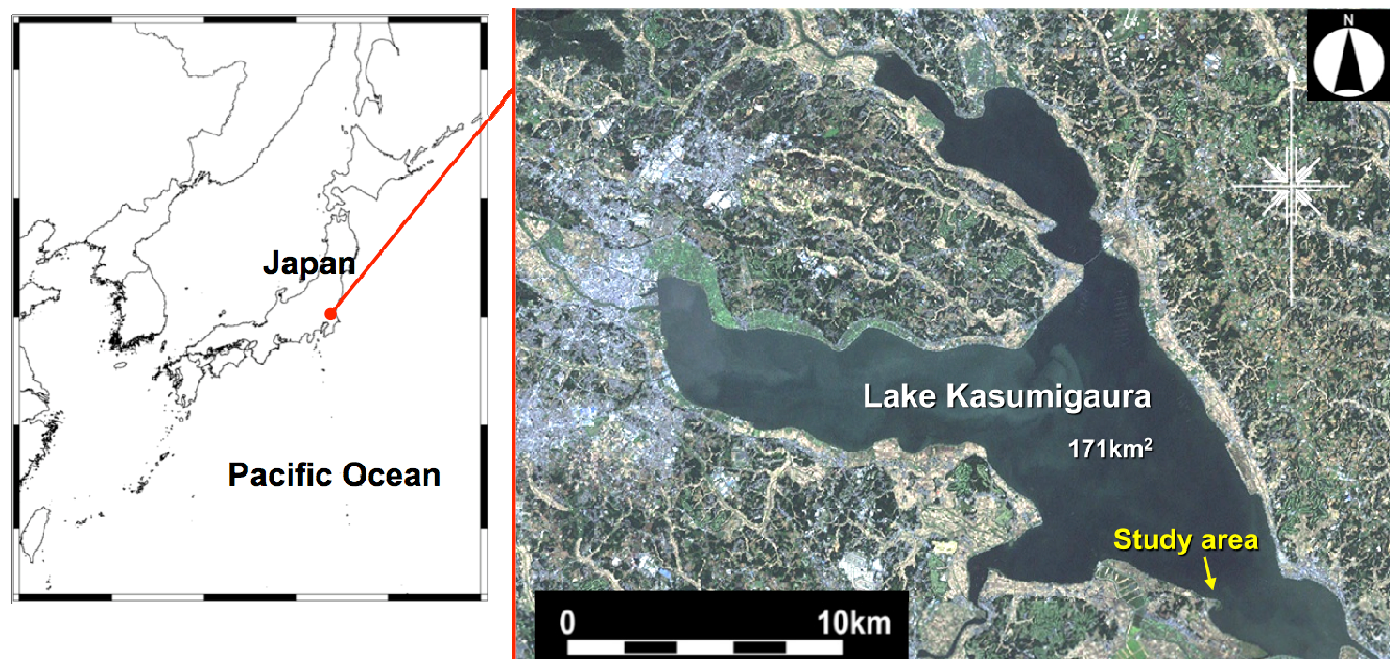

Figure 1. Location of Ukishima region of Lake Kasumigaura.

\footnotetext{
${ }^{1}$ Public Works Research Center, 1-6-4 Taito, Taito, Tokyo 110-0016, Japan

${ }^{2}$ Coastal Engineering Laboratory Co., Ltd., 301, 1-22 Wakaba, Shinjuku, Tokyo 160-0011, Japan
} 

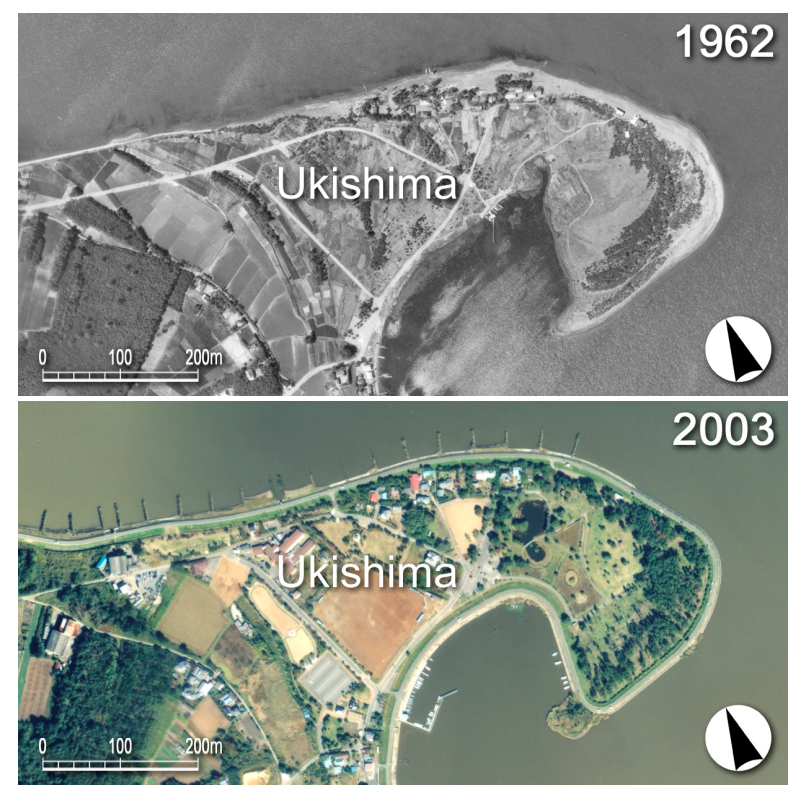

Figure 2. Changes in lakeshore between 1962 and 2003.

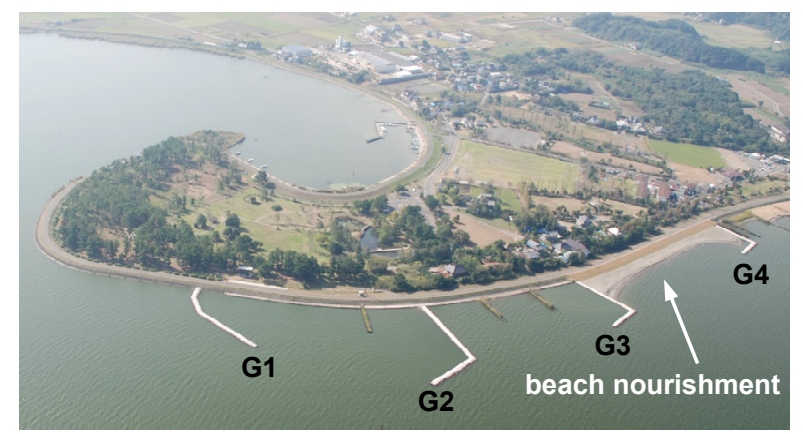

Figure 3. Experimental beach nourishment along with the construction of groins.

\section{METHOD OF FIELD EXPERIMENT}

In 2007 four groins (G1-G4) were constructed and beach nourishment was experimentally carried out between G3 and G4 in the Ukishima region using sand with a median diameter of $0.7 \mathrm{~mm}$ dredged from the lakebed, as shown in Fig. 3. Although the nourished beach was stable during the summer, storm waves in winter generated by strong wind from the WNW direction, which makes an angle of $72.5^{\circ}$ with the direction normal to the shoreline, caused large beach changes; the shoreline markedly retreated on the east side of G4, exposing the concrete revetment of the dike, which was previously under the earth. To investigate the shoreline changes, oblique aerial photographs of the Ukishima region were taken and were transformed into vertical photographs using a geometrical transformation method. The bathymetric changes were also monitored along seven transects.

\section{RESULTS OF FIELD OBSERVATIONS}

\section{Shoreline changes}

Figure 4 shows aerial photographs taken between June 14, 2007 and March 27, 2008 in the study area between G3 and G4. G4 is located at the west end of the study area and the interval between groins is $200 \mathrm{~m}$. These images were produced from oblique aerial photographs using a geometrical transformation. The shoreline between G3 and G4 extended parallel to the seawall on June 14, 2007 immediately after the nourishment, as shown in Fig. 4. The photograph taken on September 25 shows that sand was deposited behind G4 as a result of westward longshore sand transport generated by the easterly wave incidence in summer. As shown in the photograph taken on October 25 , a salient was formed behind G4 and the shoreline also advanced in the vicinity of G3. Although the shoreline 
changes were relatively small until October 25 , the shoreline had markedly retreated east of G4 by February 29, 2008, forming a hooked shoreline, and the shoreline simultaneously advanced up to the offshore corner of G3. Thus, in winter significant lakeshore changes occurred as a result of the oblique wave incidence from the west with a large incident angle. The direction of longshore sand transport, however, had changed from eastward to westward by March 27 and the shoreline receded immediately to the west of G3.
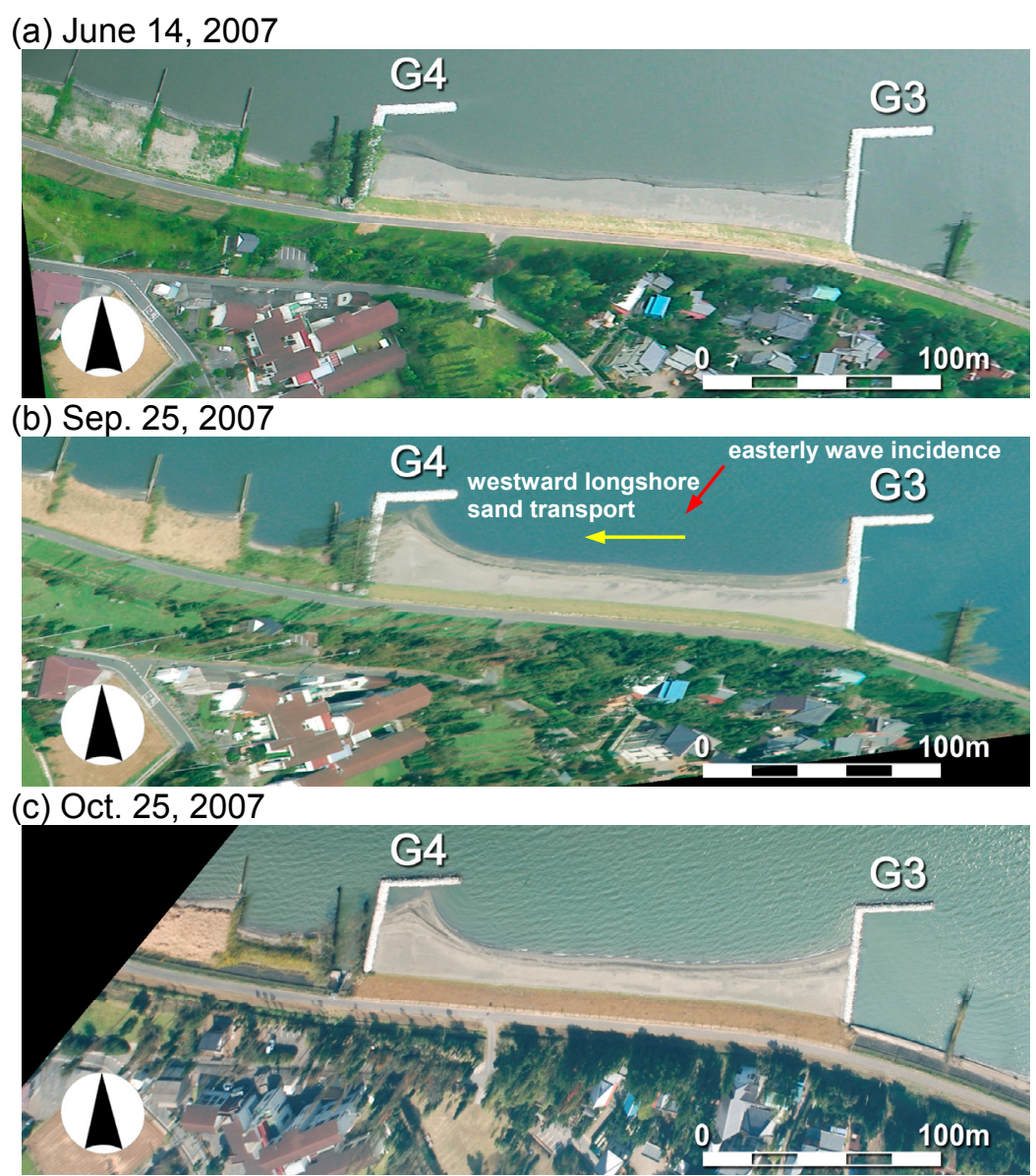

(d) Feb. 29, 2008

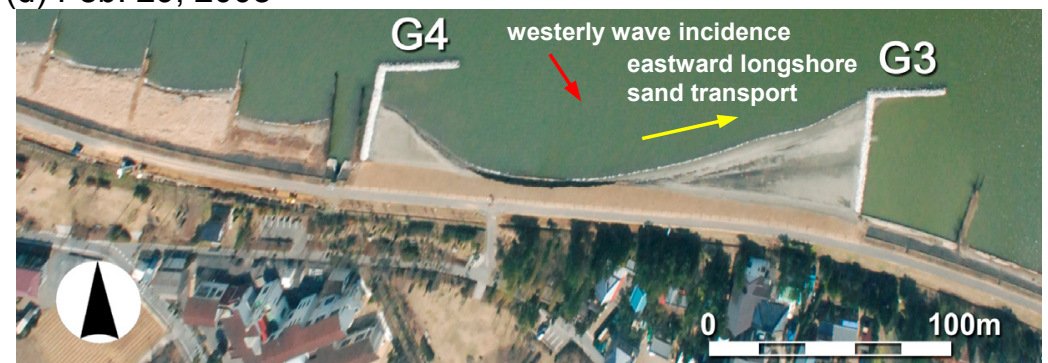

(e) Mar. 27, 2008

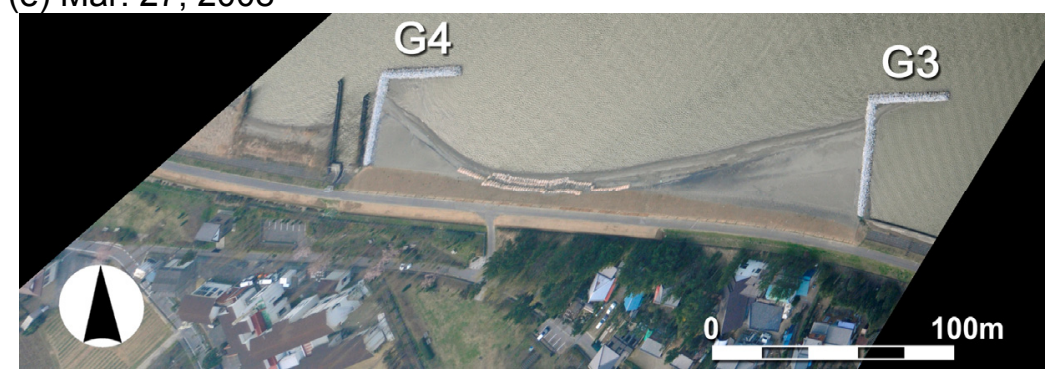

Figure 4. Sequence of beach changes in the study area. 
Figure 5 shows the shoreline changes determined from both aerial photographs and sounding data between June 14, 2007 and March 27, 2008. Here, the shoreline is defined by the line where the mean water level of this lake $(+1.1 \mathrm{~m}$ above the datum level of this lake :Y.P. $0 \mathrm{~m})$ intersects the longitudinal profile. Although the shoreline extended parallel to the seawall on June 14, it had slightly retreated by October 25 and a salient had formed behind G4. These shoreline changes were due to westward longshore sand transport because of the oblique wave incidence from the east in summer. The salient behind G4 had disappeared by November 13 and the shoreline retreated in almost the entire area between G3 and G4 relative to the shoreline position immediately after the nourishment, except for the area east of G3 where sand was deposited. This implies that not only longshore sand transport but also offshore sand transport had occurred by November 13. Then, the shoreline markedly retreated east of G4 from November 13, 2007 to February 15, 2008, whereas it advanced immediately west of G3. By February 15 , the shoreline had rotated $18^{\circ}$ counterclockwise relative to the direction of the shoreline on June 14. The shoreline rotation continued until February 29, resulting in the further disappearance of the foreshore, but from March 27 clockwise rotation of the shoreline again occurred.

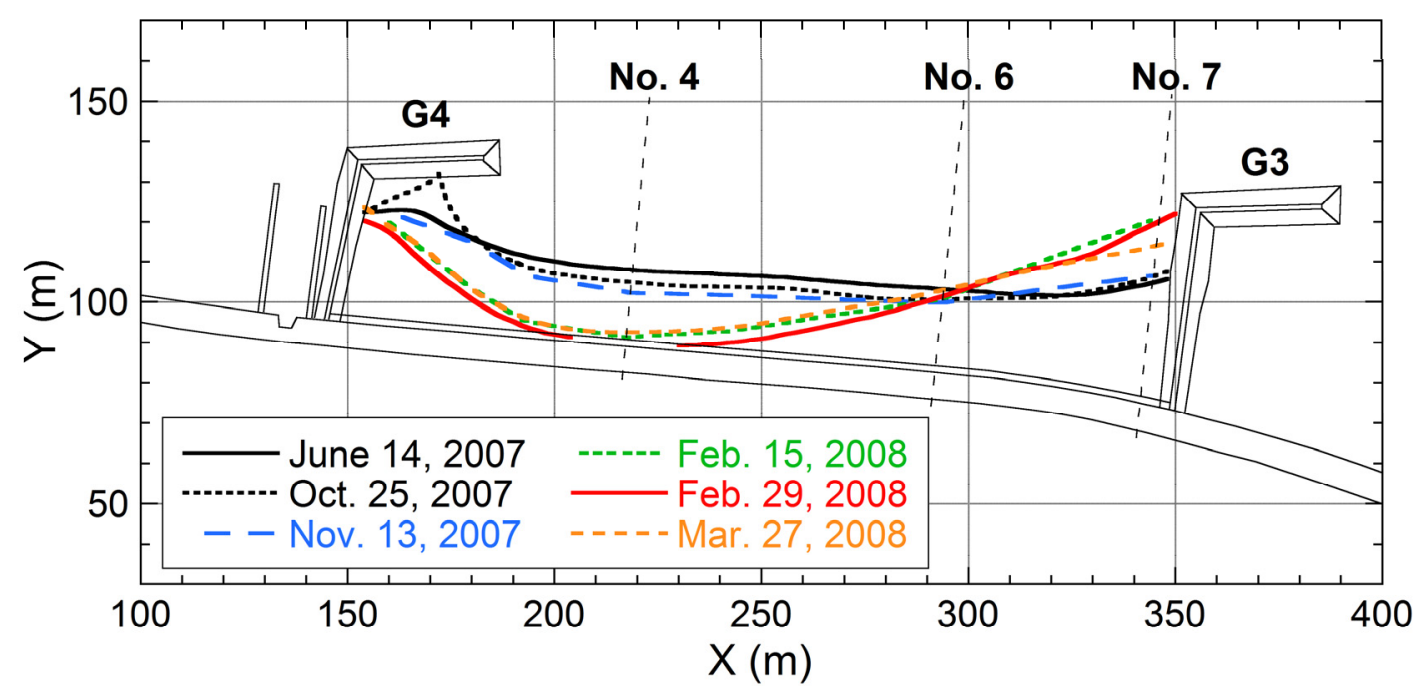

Figure 5. Shoreline changes after the beach nourishment.

\section{Change in longitudinal profile}

Figure 6 shows the longitudinal profile along transect No. 4, where the shoreline markedly receded. $Z$ is the elevation above the datum level of the lake (Y.P. $0 \mathrm{~m}$ ). The longitudinal profile between the shoreline $(Z=1.1 \mathrm{~m})$ and $Z=0.2 \mathrm{~m}$ was stable with a slope of $1 / 14$ until November 13 , after which the shoreline retreated up to the toe of the dike. By February 15, a scarp of $1 \mathrm{~m}$ height had formed along with a gentle slope of $1 / 35$ in the offshore zone. Part of the sand was deposited in the zone deeper than $Z=0.4 \mathrm{~m}$, forming a gentle slope, suggesting the discharge of fine sand from the shoreline zone. Along transect No. 6, close to the equilibrium point with no movement of the shoreline, no significant beach changes were observed except for a change in the location of the berm. However, sand was also deposited in the zone deeper than $Z=0.4 \mathrm{~m}$ and the channel located in the offshore zone was buried with sand. On the other hand, the beach slope between the shoreline and $Z=-0.2 \mathrm{~m}$ remained constant at $1 / 14$.

Along transect No. 7, close to G3, a large amount of sand was deposited on the gentle slope between $Z=0.6 \mathrm{~m}$ and $0.8 \mathrm{~m}$, which had formed before November 13 , resulting in a shoreline advance of $15 \mathrm{~m}$. A steep slope of $1 / 14$ was formed between the shoreline and $Z=-0.2 \mathrm{~m}$ because of the sand deposition on the shore face and a berm developed up to an elevation of $Z=1.6 \mathrm{~m}$, whereas sand was deposited up to a depth of $Z=-0.4 \mathrm{~m}$ in the offshore zone. Although the tip of $\mathrm{G} 3(Y=-52 \mathrm{~m})$ is also shown in the longitudinal profile along transect No. 7, the offshore deposition zone extended offshore beyond the tip of the groin. This means that part of the sand was transported east of G3, turning around its tip, because of the large wave incidence counterclockwise relative to the shoreline. 

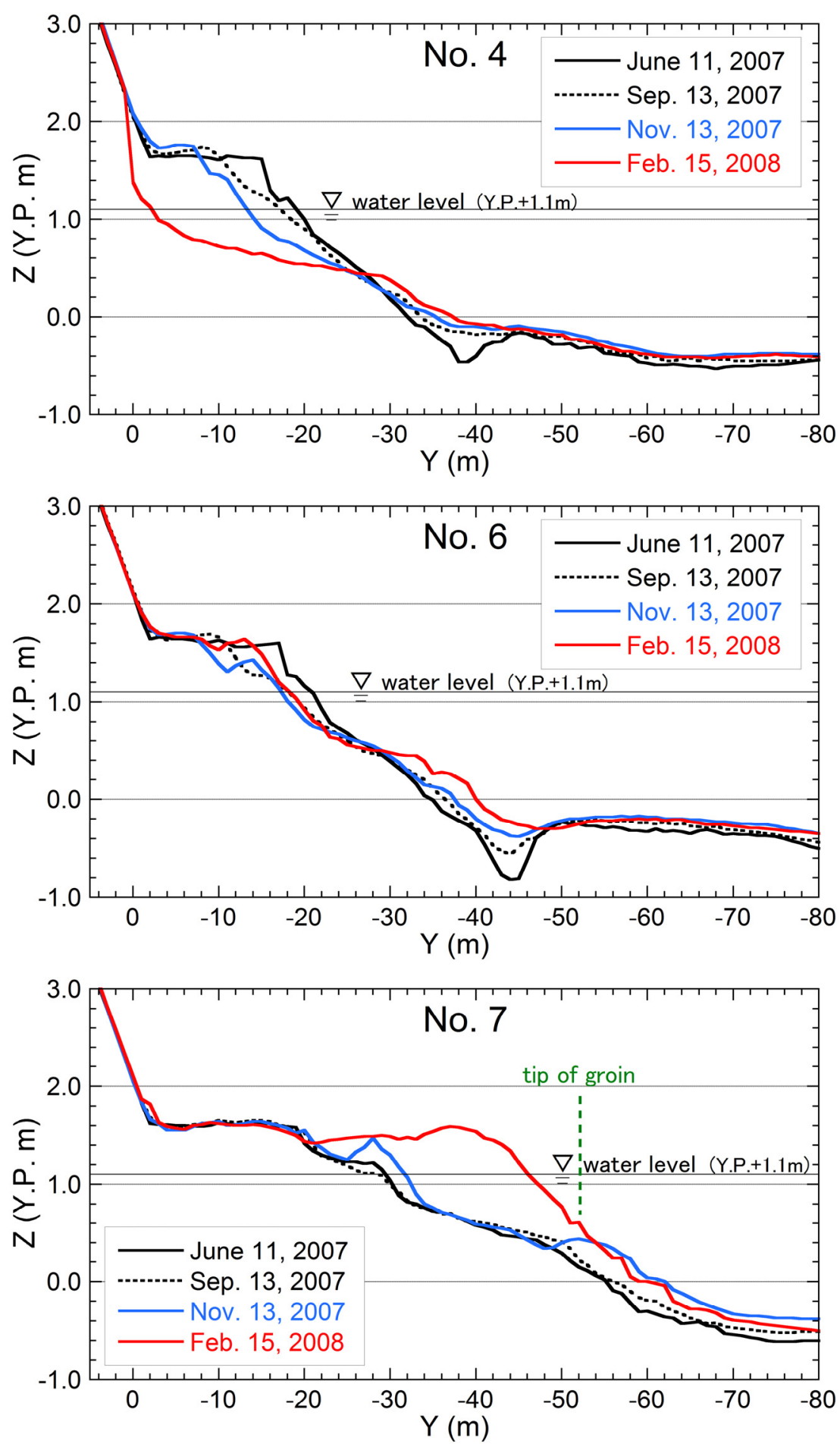

Figure 6. Longitudinal profiles along transect Nos. 4, 6 and 7.

\section{Change in cross-sectional area}

Figure 7 shows the longshore distribution of the change in cross-sectional area between June 11, 2007 and February 15, 2008. The calculation zone of the cross-sectional area was separated into two zones, shallower and deeper than $Z=0.4 \mathrm{~m}$, to separately evaluate the effects of longshore and crossshore sand transport. In the depth zone shallower than $Z=0.4 \mathrm{~m}$, the cross-sectional area decreased west of $X=150 \mathrm{~m}$, whereas it increased east of $X=150 \mathrm{~m}$ except in the vicinity of G4. This change is similar to the shoreline change shown in Fig. 5, and it can be concluded that it was caused by the eastward 
longshore sand transport. In contrast, in the zone deeper than $Z=0.4 \mathrm{~m}$, uniform sand deposition occurred regardless of the longshore location, although the change was slightly larger in the area east of transect No. 4 that was located outside the wave-shelter zone of G4 than that in the western part. These findings infer that part of the nourished sand was transported offshore because fine sand was contained in the nourishment material.

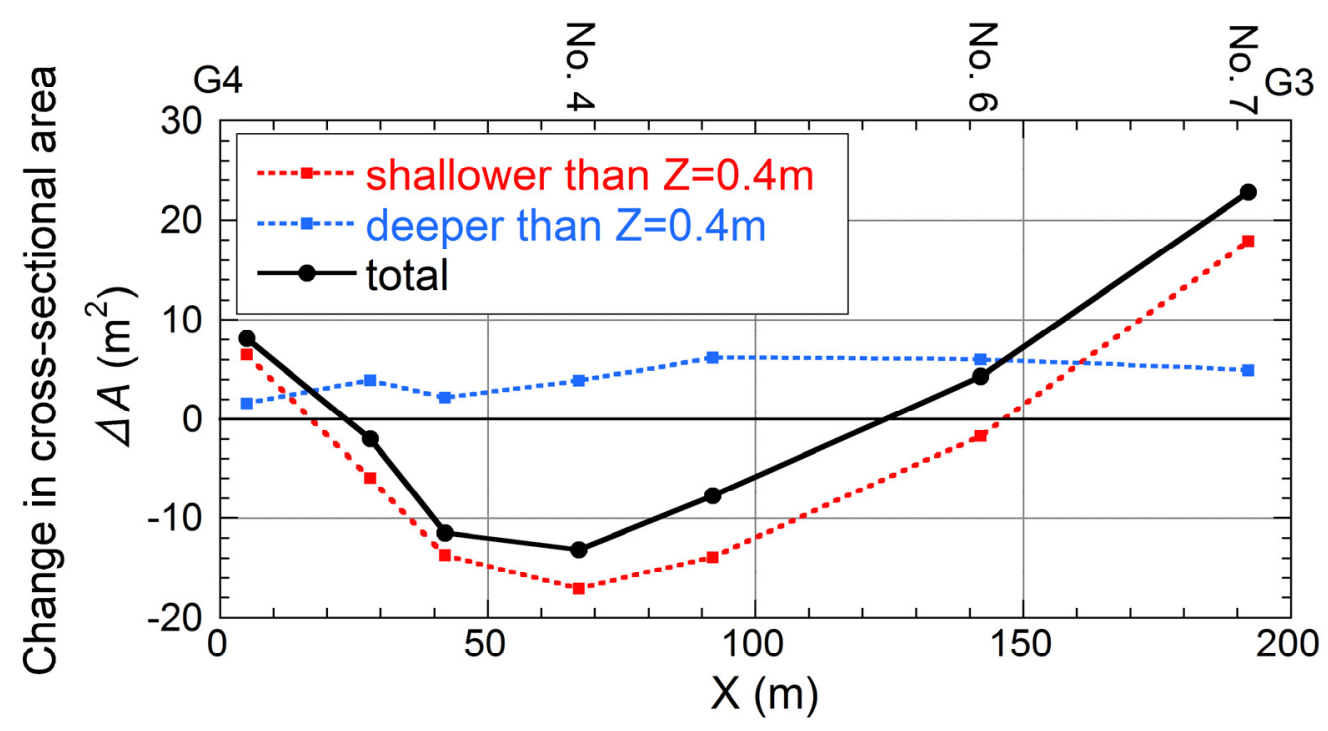

Figure 7. Longshore distribution of change in cross-sectional area.

\section{WAVE AND WIND CONDITIONS IN STUDY AREA}

The change in water level of the lake between January 2007 and May 2008 measured at the Ukishima observatory is shown in Fig. 8(a). During the rainy season in summer, a rapid increase in water level, with $Z$ reaching $1.5 \mathrm{~m}$, occurred three times due to the heavy rainfall caused by typhoons T0704 on July 14, T0709 on September 6 and T0720 on October 27. Apart from during these rapid rises in water level, the water level in summer was approximately $Z=1.1 \mathrm{~m}$, whereas in winter the lake level rose from December to almost $Z=1.3 \mathrm{~m}$, which is the artificially raised level when the lake is used for preparing water resources.

Figure 8(b) shows the change in significant wave height in the Ukishima region calculated hourly using the SMB method from the wind velocity and its direction between January 1, 2007 and April 22, 2008 measured at the observatory in the center of lake and the directional fetch in the Ukishima region. The change in significant wave height clearly shows one-year periodicity, i.e., in summer the lake is generally calm, whereas high waves are incident in winter. Both the approximately $0.2 \mathrm{~m}$ higher lake level in winter compared with that in summer and the higher waves in winter are the main causes of the significant beach changes in winter.

From the wind direction measured hourly at the observatory in the center of the lake, the mean wave direction was determined as a moving average over 24 hours, excluding wind directions resulting in no fetch in the Ukishima region. Figure 8(c) shows the change in the mean wave direction between January 2007 and April 22, 2008. The discontinuity of the mean wave direction corresponds to the calm condition. The variation of the mean wave direction, plotted as a broken line in the figure, clearly shows a distinctive one-year periodicity with the wave direction from NE in summer and NW in winter. Furthermore, the energy-mean wave direction between May 10, 2007, immediately after the nourishment, and April 22, 2008 is $\mathrm{N} 5^{\circ} \mathrm{W}$ and the wave direction changes cyclically around this mean wave direction. As the extreme values of wave direction, ENE $\left(\mathrm{N} 67.5^{\circ} \mathrm{E}\right)$ and $\mathrm{WNW}\left(\mathrm{N} 67.5^{\circ} \mathrm{W}\right)$ were observed in summer and winter, respectively, which make much larger wave angles relative to the mean wave direction of $\mathrm{N} 5^{\circ} \mathrm{W}$, although the duration of waves in these directions was as short as approximately 1 day. Table 1 shows the energy-mean wave height calculated from the data set between March 2007 and April 2008. The energy-mean wave directions in summer and winter were $\mathrm{N} 34^{\circ} \mathrm{E}$ and $\mathrm{N} 32^{\circ} \mathrm{W}$, respectively. 
(a) Water level

Nov. 13, 2007 - Feb. 29, 2008

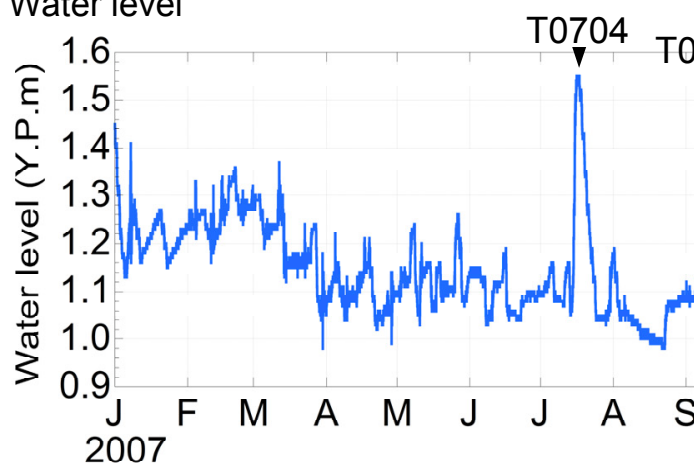

(b) Wave height

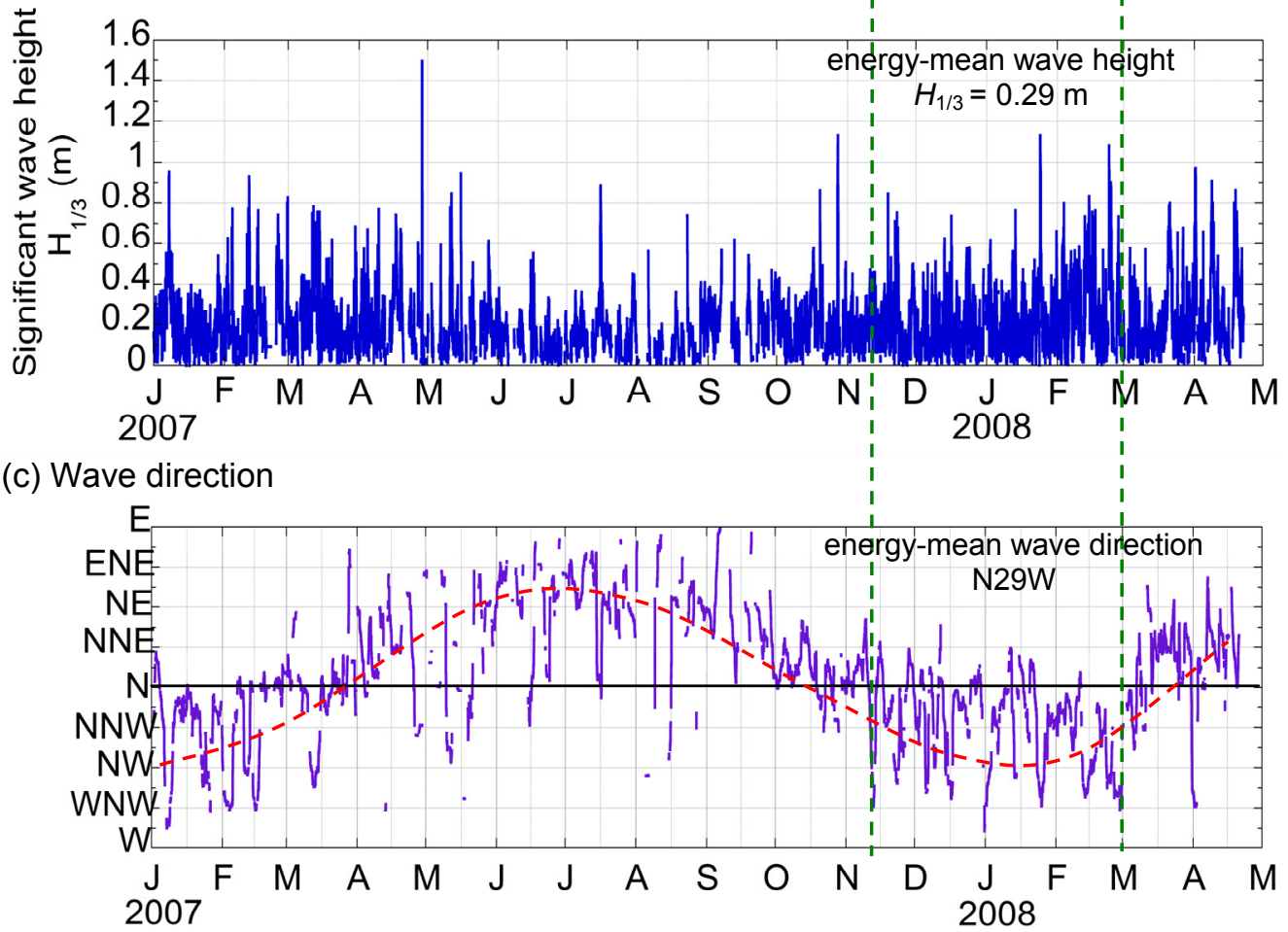

Figure 8. Waves and wind conditions during experimental period.

\begin{tabular}{|l|l|l|l|}
\hline \multicolumn{4}{|c|}{ Table 1. Energy-mean wave height, wave period and wave direction. } \\
\hline Duration & $H_{1 / 3}(\mathrm{~m})$ & $T_{1 / 3}(\mathrm{~s})$ & Wave direction \\
\hline $\begin{array}{l}\text { Entire period after nourishment } \\
\text { May 10, 2007 - Apr. 22, 2008 }\end{array}$ & 0.25 & 1.5 & $\mathrm{~N} 5^{\circ} \mathrm{W}$ \\
$\begin{array}{l}\text { Reproduction period in 2008 } \\
\text { Nov. 13 - Feb. } 29\end{array}$ & 0.29 & 1.6 & $\mathrm{~N} 29^{\circ} \mathrm{W}$ \\
$\begin{array}{l}\text { Spring in 2007 } \\
\text { Mar. 1 - May 31 }\end{array}$ & 0.24 & 1.6 & $\mathrm{~N} 5^{\circ} \mathrm{W}$ \\
$\begin{array}{l}\text { Summer 2007 } \\
\text { June 1 - Aug. 31 } \\
\text { Autumn 2007 } \\
\text { Sep. 1 - Nov. 30 } \\
\text { Winter 2007 } \\
\text { Dec. 1- Feb. 29, 2008 }\end{array}$ & 0.18 & 1.3 & $\mathrm{~N} 34^{\circ} \mathrm{E}$ \\
\hline
\end{tabular}




\section{PREDICTION OF BEACH CHANGES USING BG MODEL}

\section{Model}

Assume that the sand transport due to waves $\overrightarrow{q_{w}}$ is defined by Eq. (1) (Serizawa et al., 2006). Consider Cartesian coordinates $(x, y)$ and that the elevation at a point $Z(x, y, t)$ is a variable to be solved. Assume that waves are obliquely incident on a coast with a uniform slope of $\tan \beta$. Then, the net sand transport flux due to waves can be written as

$$
\overrightarrow{q_{w}}=\frac{G_{w}}{\tan \beta_{\mathrm{c}}}\left[\tan \beta_{\mathrm{c}} \overrightarrow{e_{w}}-\nabla Z\right]
$$

Here, $\overrightarrow{e_{w}}=\left(\cos \theta_{w}, \sin \theta_{w}\right)$ is the unit vector in the wave direction $\theta_{w}$ and $\nabla Z=(\partial Z / \partial x, \partial Z / \partial y)$ is the gradient vector of $Z$, the direction and magnitude of which give the shoreward normal to the contour line and $\tan \beta$, respectively. $\tan \beta_{\mathrm{c}}$ is the equilibrium slope resulting in zero net on-offshore sand transport when waves are incident from the direction normal to the shoreline. $G_{w}$ is expressed in terms of the wave energy flux at the breaking point. The coastal domain is discretized using 2-D elements with widths $\Delta x$ and $\Delta y$. The explicit finite-difference method is used to solve the equations.

\section{Validation calculation}

The measured beach topography was reproduced using the BG model. The calculation domain has a length of $500 \mathrm{~m}$ alongshore and a $300 \mathrm{~m}$ width between G3 and G4 in the Ukishima region. The initial topography used in the calculation was set as a solid bed using the lakeshore topography before the nourishment, as shown in Fig. 9(a), and the beach nourishment was assumed to carry out in a rectangular zone with a width of $25 \mathrm{~m}$ between groins on a solid bed. Table 2 shows the calculation conditions. The groins have an impermeable structure. Beach changes were mainly triggered by longshore sand transport, as indicated by the change in the longitudinal profiles in Figs. 5 and 6. Therefore, sand with a single grain size of median diameter $\mathrm{d}_{50}=0.7 \mathrm{~mm}$ was considered, and the equilibrium slope of this sand was assumed to be $1 / 14$ on the basis of monitoring survey data, as shown in Fig. 6.

For the incident waves, the energy-mean wave height during the reproduction period shown in Table 1 was given. The irregular wave field was determined using the angular spreading method for irregular waves (Sakai et al., 2006) given the condition $S_{\max }=10$, and the wave-sheltering effect of the groins was taken into account. The beach changes after the nourishment were predicted under these conditions using the BG model. For the lake level, the mean water level of $Z=1.3 \mathrm{~m}$ in winter was adopted. The height of the nourishment beach was assumed to be $Z=1.6 \mathrm{~m}$. The other coefficients are shown in Table 2.

Because the marked topographic changes occurred between November 13 and February 29, we first reproduced the topography on November 13. For the wave conditions before November 13, the same energy-mean significant wave height and oblique wave incidence from $\mathrm{N} 29^{\circ} \mathrm{W}$ as that between November 13 and February 29, as shown in Table 1, were assumed and the best-fit solution of the shoreline configuration measured on November 15 shown in Fig. 5 was obtained, given the initial beach topography. Figure 9(b) shows the reproduced beach topography on November 13, 2007. Predicted shoreline is in good agreement with the measured shoreline. Then, the topography on February 29 was reproduced. Figure 9(c) shows the beach topography on February 29, 2008, predicted under the condition of oblique wave incidence from $\mathrm{N} 29^{\circ} \mathrm{W}$ given the reproduced beach topography on November 13. Because waves incident from $\mathrm{N} 29^{\circ} \mathrm{W}$ make a large angle with the shoreline and it becomes the westerly wave direction, eastward longshore sand transport was generated and sand was transported toward G3, part of which was further transported to the zone between G2 and G3, turning around the tip of G3. This result was in good agreement with the features shown in Fig. 5. After turning around the tip of G3, sand then moved shoreward and $700 \mathrm{~m}^{3}$ of sand was deposited between G2 and G3. Thus, the BG model is suitable for predicting the movement of sand when it is transported downcoast while forming a sand deposition zone at the tip of a groin in the form of a sand spit.

Figure 9(d) shows the predicted and measured shorelines, which are in good agreement. It was found that the length of G3 was too short to prevent sand turning around its tip when waves are obliquely incident from $\mathrm{N} 29^{\circ} \mathrm{E}$ with a large breaker angle, suggesting the necessity of constructing a 
spur dike at the tip of G3 to prevent sand from turning around the groin when fine sand with the same grain size is used for beach nourishment.

(a) Initial beach topography on June 14, 2007

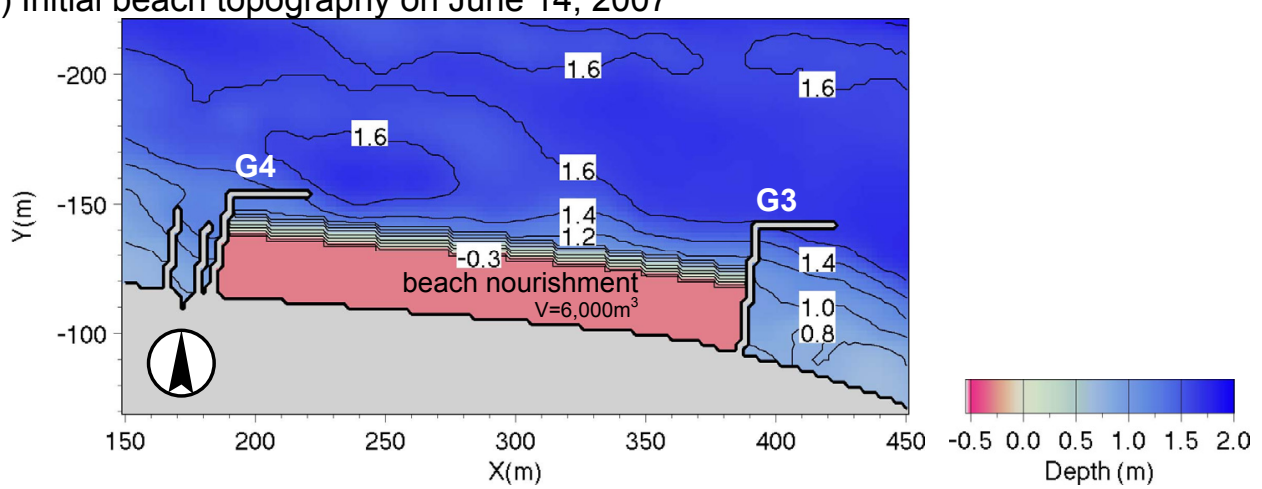

(b) Reproduced beach topography on November 13, 2007

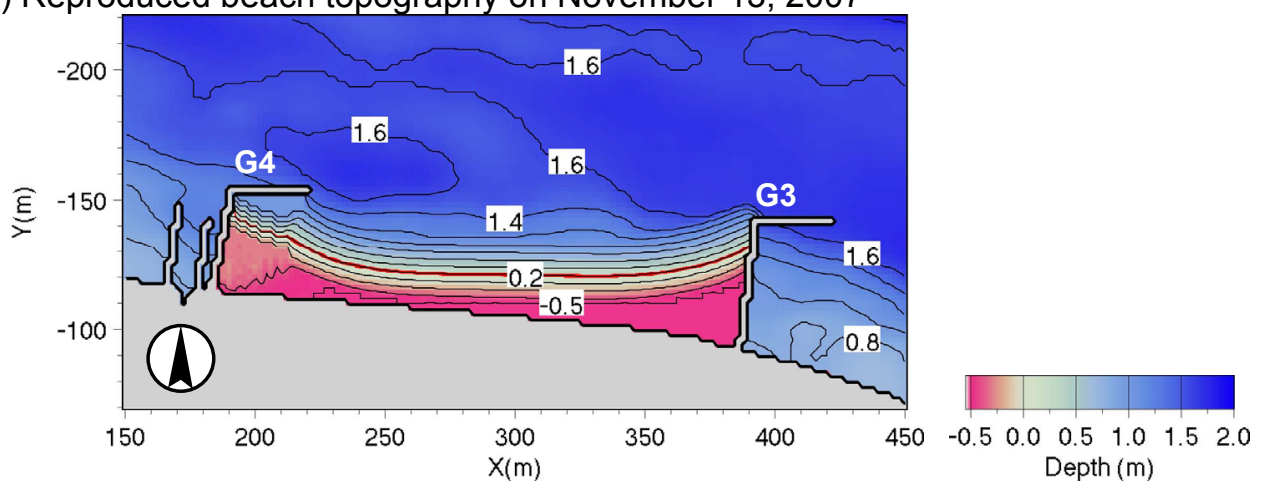

(c) Reproduced beach topography on Feb. 29, 2008.

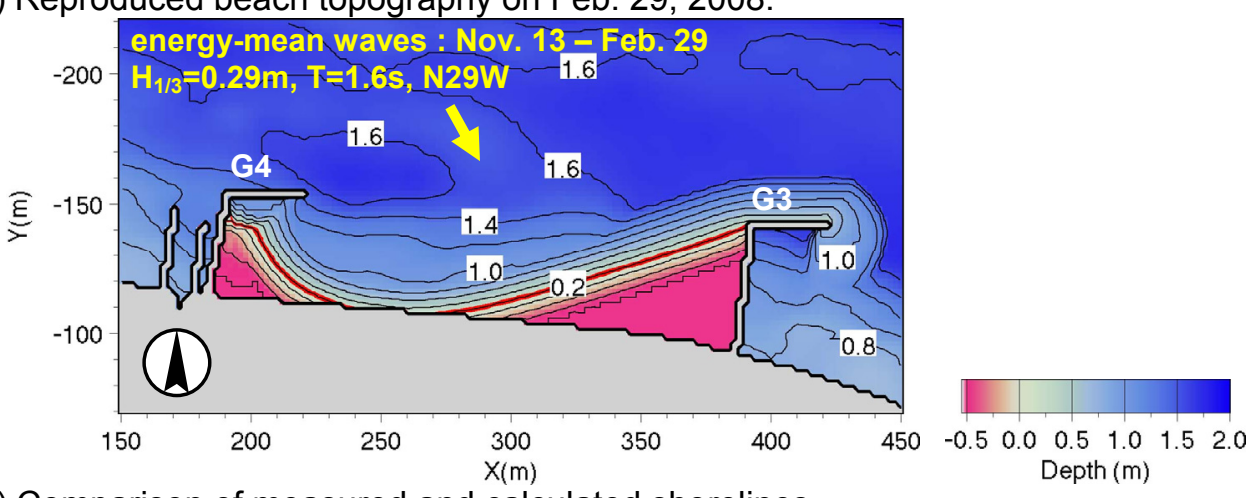

(d) Comparison of measured and calculated shorelines.

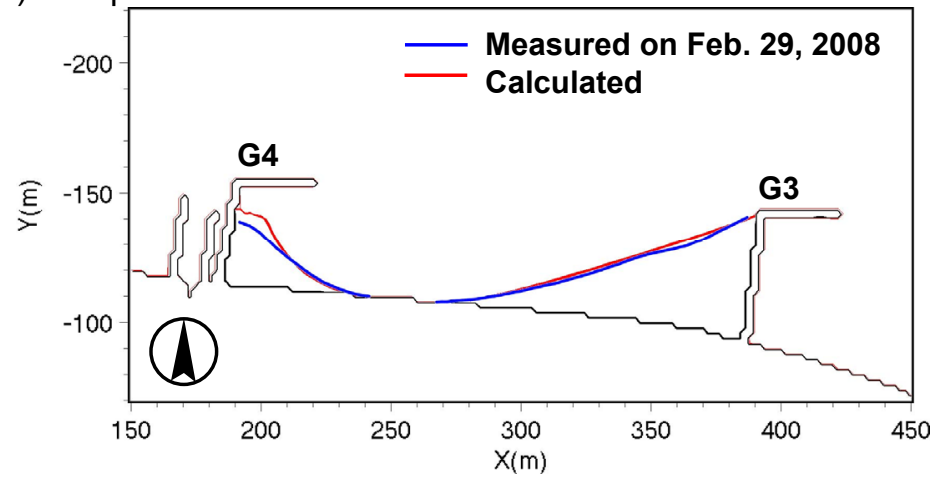

Figure 9. Reproduction of beach changes between June 14, 2007 and February 29, 2008. 


\begin{tabular}{|c|c|}
\hline Calculation method & $\begin{array}{l}\text { BG model (Serizawa et al., 2006) } \\
\text { Angular spreading method for irregular waves (Sakai et al., 2006) }\end{array}$ \\
\hline Calculation domain & Rectangular area with $500 \mathrm{~m}$ length and $300 \mathrm{~m}$ width \\
\hline Reproduction period & Between November 13, 2007 and February 29, 2008 \\
\hline Initial topography & Bathymetry in March $2002+$ beach nourishment \\
\hline Incident wave condition & $\begin{array}{l}\text { Energy-mean waves (Table 1): } H_{1 / 3}=0.29 \mathrm{~m}, T_{1 / 3}=1.6 \mathrm{~s}, \\
\theta=\mathrm{N} 29^{\circ} \mathrm{W}, S_{\max }=10\end{array}$ \\
\hline Duration of calculation & 108 days \\
\hline Water level & $Z=1.3 \mathrm{~m}$ above reference level of lake \\
\hline Mesh interval & $\Delta x=\Delta y=2 \mathrm{~m}$ \\
\hline Time interval & $\Delta t=0.1 \mathrm{hr}$ \\
\hline Grain size and equilibrium slope & $0.6 \mathrm{~mm}$ and $\tan \beta=1 / 14$ \\
\hline Critical slopes on land and seabed & $1 / 2$ and $1 / 3$ \\
\hline $\begin{array}{l}\text { Depth distribution of longshore } \\
\text { sand transport }\end{array}$ & Cubic equation by Uda and Kawano (1996) \\
\hline Depth of closure & $h_{c}=1.5 \mathrm{~m}(Z=-0.2 \mathrm{~m})$ \\
\hline Berm height & $h_{R}=0.5 \mathrm{~m}(Z=1.8 \mathrm{~m})$ \\
\hline $\begin{array}{l}\text { Coefficients of longshore sand } \\
\text { transport }\end{array}$ & $K_{1}=0.2$ and $K_{2}=1.62 K_{1}$ \\
\hline Boundary conditions & Solid wall at boundaries $(q=0)$ \\
\hline Conditions of nourishment & $\begin{array}{l}\text { Height of nourishment beach: } Z=1.6 \mathrm{~m} \text {, annual rate of beach } \\
\text { nourishment }=6,000 \mathrm{~m}^{3} / \mathrm{yr}\end{array}$ \\
\hline
\end{tabular}

\section{Effectiveness of spur dike as measure}

To prevent sand from turning around the downcoast groin, the construction of a spur dike extending parallel to the wave direction was considered to be more effective than simply extending G3, because the length of the additional part was minimal. Therefore, as a measure to stabilize the nourishment beach, the effect of a spur dike extending from the offshore corner of G3 was investigated. Because the measured beach changes were accurately reproduced using the BG model, the effect of a spur dike of $57 \mathrm{~m}$ length was predicted using this model. The length of the spur dike was determined geometrically given the wave direction, the interval between groins and the beach slope.

According to the results of the validation calculation, the shoreline significantly retreated immediately east of G4 under the action of waves in winter, and therefore, another measure was adopted to prevent the exposure of the seawall; part of the lakebed in this area with $100 \mathrm{~m}$ width and length was covered with a layer of gravel, the weight of which was sufficiently large for it not to be moved by waves. For the incident waves, the energy-mean wave height predicted using the wind data measured at the observatory in the center of the lake between 1978 and 2004, was assumed. Table 3 shows the calculation conditions.

\begin{tabular}{|c|c|}
\hline \multicolumn{2}{|c|}{ Table 3. Conditions of prediction calculation. } \\
\hline Structures & $\begin{array}{l}\text { Construction of spur dike of } 57 \mathrm{~m} \text { length }+ \text { gravel layer of } 100 \mathrm{~m} \\
\text { length }\end{array}$ \\
\hline Conditions of incident waves & $\begin{array}{l}\text { Energy-mean waves: } H_{1 / 3}=0.25 \mathrm{~m}, T_{1 / 3}=2.0 \mathrm{~s} \text { and } \theta=\mathrm{N} 29^{\circ} \mathrm{W} \\
\text { (winter), } H_{1 / 3}=0.17 \mathrm{~m}, T_{1 / 3}=1.3 \mathrm{~s} \text { and } \theta=\mathrm{N} 12^{\circ} \mathrm{W} \text { (summer) }\end{array}$ \\
\hline Duration of prediction & Three months \\
\hline Conditions of beach nourishment & $\begin{array}{l}\text { Height of nourishment beach: } \\
Z=1.8 \mathrm{~m} \text {, Volume of beach nourishment }=14,000 \mathrm{~m}^{3}\end{array}$ \\
\hline
\end{tabular}


Figure 10(a) shows the initial beach topography measured in November 2007 with the contours parallel to the seawall. Figure 10(b) shows the predicted beach topography after three months of wave action given a lake level of $Z=1.3 \mathrm{~m}$, energy-mean waves in winter $\left(H_{1 / 3}=0.25 \mathrm{~m}\right.$ and $\left.T=2.0 \mathrm{~s}\right)$ and a wave direction of $\mathrm{N}^{\circ} 9^{\circ} \mathrm{W}$. The beach topography, as shown in Fig. 10(b), has already reached a stable form. Because the wave direction from $\mathrm{N} 29^{\circ} \mathrm{W}$ makes a large angle counterclockwise relative to the shoreline, eastward longshore sand transport was generated, resulting in marked shoreline recession on the east side of G4, whereas the offshore contours advanced toward the tip of the spur dike. It is clear that sand discharge owing to eastward sand transport was completely blocked by the spur dike, and a dynamically stable lakeshore was formed despite a seasonally changing wave direction. As a result of large shoreline recession immediately east of G4, the gravel layer was exposed to waves over $20 \mathrm{~m}$ of its length. It is considered that when bed material with a large weight is used for the gravel layer, the initial beach profile can be maintained.

When the energy-mean waves with $H_{1 / 3}=0.17 \mathrm{~m}$ and $T_{1 / 3}=1.3 \mathrm{~s}$ in summer are incident from the direction of $\mathrm{N} 12^{\circ} \mathrm{W}$ under this condition, the direction of longshore sand transport changes from eastward to westward, and the contour lines, which had markedly advanced, retreat, as shown in Fig. 10(c). On the whole, the direction of the contour lines rotated clockwise and the foreshore width immediately east of G4, which was narrow after the wave action in winter, became wide. The gravel layer, temporarily exposed by the winter waves, was again buried with sand.

Figure 10(d) shows the shoreline changes during the same period. Although part of the sand was transported westward, turning around the tip of G4, the amount of such sand was minimal, and thus, the shoreline changes occurred alternately between G3 and G4 due to the seasonal changes in wave direction. It was shown that the nourishment beach can be dynamically stable except for the offshore movement of fine sand due to sorting by waves. The volume of fine sand discharged offshore was sufficiently small for its effect to be neglected in this study. Such an effect can be accurately predicted using the BG model considering the grain size of sand proposed by Noshi et al. (2009).

(a) Initial beach topography

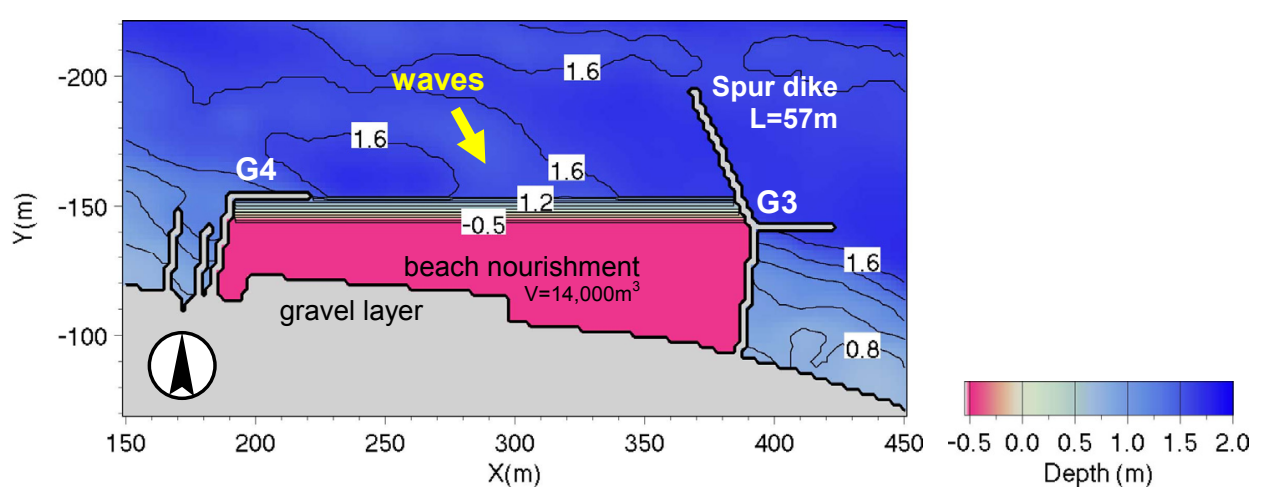

(b) Predicted beach topography after 3 months of wave action given energy-mean waves of $\mathrm{N} 29^{\circ} \mathrm{W}$ in winter.

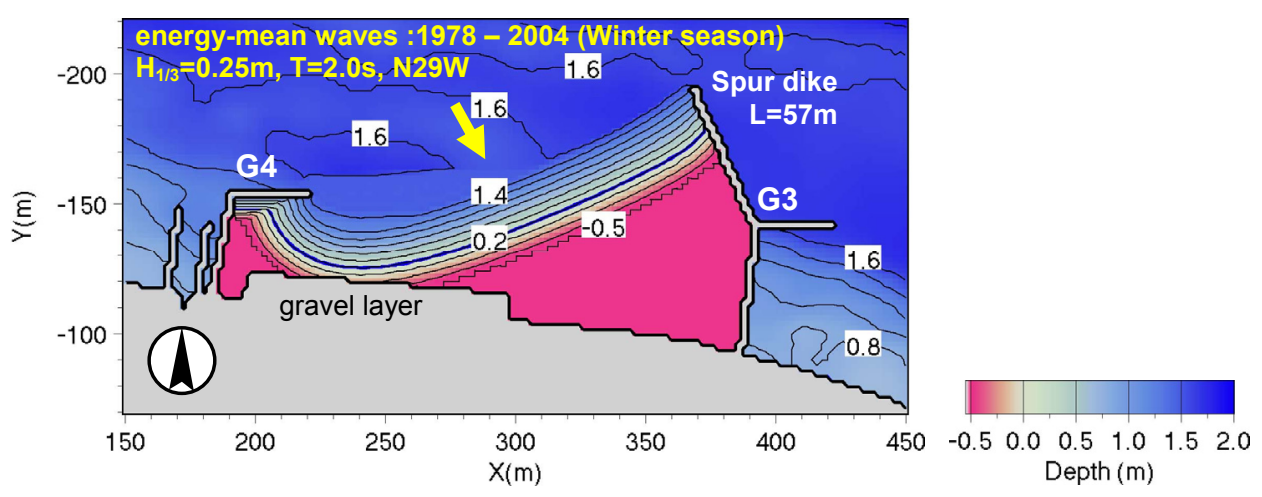

Figure 10. Prediction of beach changes of effectiveness of spur dike as measure. 
(c) Predicted beach topography after 3 months of wave action given energy-mean waves of $\mathrm{N} 12^{\circ} \mathrm{W}$ in summer.

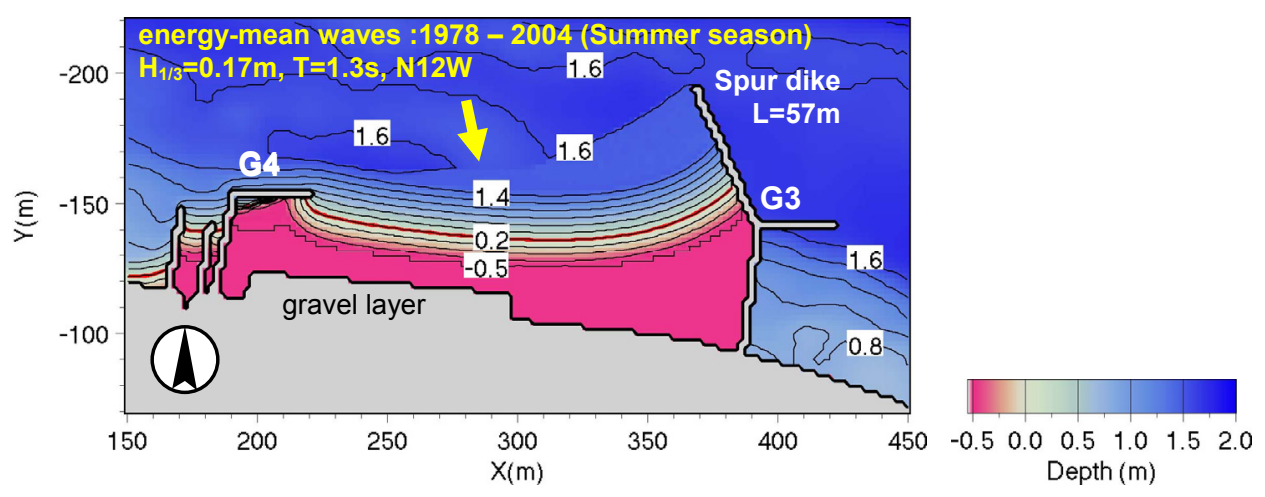

(d) Predicted shoreline changes during the same period.

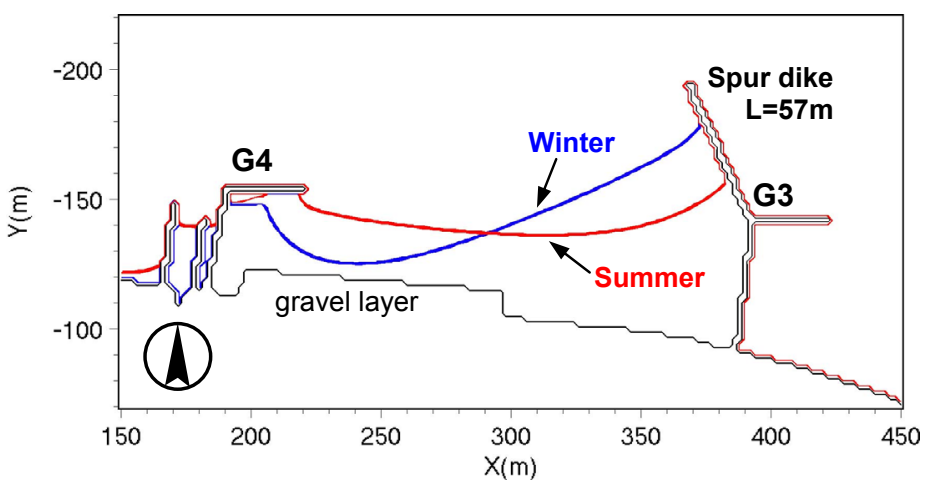

Figure 10. Prediction of beach changes of effectiveness of spur dike as measure (continued).

\section{CONCLUSIONS}

A field experiment on the formation of a dynamically stable lakeshore was carried out at Lake Kasumigaura, where the wave direction seasonally changes. Alternate shoreline changes were observed between groins in response to the change in wave direction. The effect of oblique wave incidence on the shoreline was investigated through the analysis of monitoring survey data. Beach changes were predicted using the BG model (Serizawa et al., 2006) under the condition that the winter and summer waves are incident from $\mathrm{N} 29^{\circ} \mathrm{W}$ and $\mathrm{N} 12^{\circ} \mathrm{W}$, respectively. The predicted and measured beach changes were in good agreement and the effectiveness of the numerical model was confirmed. It was found that the length of the downcoast groin was too short to prevent sand from being transported around its tip, and therefore, as a measure to stabilize the nourishment beach, a spur dike with an optimum length was shown to be effective.

\section{REFERENCES}

Noshi, Y., A. Kobayashi and T. Uda. 2009. Model for predicting bathymetric and grain size changes considering equilibrium beach slopes corresponding to composition of grain size and each grain size, Jour. Coastal Res., SI 56, Portugal, 108-112.

Sakai, K., T. Uda, M. Serizawa, T. Kumada and Y. Kanda. 2006. Model for predicting threedimensional sea bottom topography of statically stable beach, Proc. 30th ICCE, 3184-3196.

Serizawa, M., T. Uda, T. San-nami and K. Furuike. 2006. Three-dimensional model for predicting beach changes based on Bagnold's concept, Proc. 30th ICCE, 3155-3167.

Uda, T., T. Yamamoto, N. Itabashi and K. Yamaji. 1996. Field observation of movement of sand body due to waves and verification of its mechanism by numerical model, Proc. 25th ICCE, 137-150. 